\title{
Analyzing the Cyberbullying Behaviors of Sports College Students
}

\author{
Yahya Dogar ${ }^{1}$ \\ ${ }^{1}$ Faculty of Sport Sciences, Inonu University, Turkey \\ Correspondence: Yahya Dogar, Faculty of Sport Sciences, Inonu University, Turkey.
}

Received: May 23, 2019

doi:10.5539/ies.v12n11p36
Accepted: July 30, 2019 Online Published: October 25, 2019

URL: https://doi.org/10.5539/ies.v12n11p36

\begin{abstract}
Studies conducted show that verbal and physical aggressive behaviors particularly among students are affected by the cyberbullying behaviors that are recently becoming even more prevalent with the increase in the social media tools. Such a case may also raise the need for investigating the cyberbullying behaviors of students of sports education in particular. Therefore, the aim of this study is to determine the cyberbullying behaviors of Sports College students. The sample of the study consists of 658 students (465 males and 193 females) studying at Sports Colleges in four different cities in Turkey. Among the quantitative research methods, scanning method has been used in the study. The "Cyberbullying Scale of Sports Audience" developed by Dogar and Karaca (2019) has been used in the study as data collection tool. It consists of 7 questions, which have one-dimension and 5-point Likert scale. The data obtained has had normal distribution. The student t-test has been used for dual comparisons, and one-way analysis of variance (ANOVA) with Tukey post hoc test has been used for multiple comparisons. The level of significance has been selected as $p<.05$. The findings of the study have revealed that there were statistically significant differences between the cyberbullying behaviors of Sports College students and their age, sex, educational status of parents, means of following matches, frequency of watching matches, attending to away matches, membership of sports associations, social media accounts, purposes and levels of using such accounts. As a conclusion, it was found out that the efforts of students and teachers alone will not be sufficient in preventing the cyberbullying behaviors. The families, society and the government should also be sensitive of this issue for a solution.
\end{abstract}

Keywords: cyberbullying, sports college students, social media and cyberbullying

\section{Introduction}

With the advancements in the means of communication, a new era has begun regarding the communication among people. Face-to-face contact and communication have mostly been replaced by the social media; so, a new lifestyle has developed. This new lifestyle has many advantages, such as providing individuals with the opportunity of communicating online and simultaneously, allowing individuals to access information sources quickly and offering them opportunities for socialization. However, it has also brought along serious issues. One of the important issues that have emerged especially with the widespread use of the Internet is that the bullying behaviors exhibited by students at schools have now been moved to the cyber platform. This has resulted in the emergence of a new type of bullying called cyberbullying.

Cyberbullying is defined as threatening, humiliating or sending sexually explicit pictures and messages to other individuals through websites, instant messaging, blogs, chat rooms, smart phones, electronic mail and personal online profiles (Kowalski \& Limber, 2012). Cyberbullying is more common and dangerous than other forms of bullying, such as verbal, physical and relational bullying. Since the cyberbullies can hide their identity during cyberbullying, it is difficult to control the cyber environment and the cyberbully can reach a large number of people in a short time and cyberbullying does not involve face-to-face communication. Considering that $67 \%$ of the population in Turkey (54.3 million) uses the Internet, 51.1\% (51 million) actively uses social media, and 54\% (44 million) actively uses mobile social media, the situation becomes even more important (Cengizhan, 2018). This data resembles similarities with developed countries, as well. In the UK, for example, cyberbullying potential has risen among the youth who use networked computers and mobile phones; $51 \%$ of 10 -year-olds and $91 \%$ of 12-year-olds have mobile phones (Peter et al., 2008). Manap (2012), called attention to the seriousness of the issue by emphasizing that cyberbullying could turn into physical bullying if it was not prevented.

It is seen that exposure to cyberbullying among students is associated with skipping classes, dropping out of 
school, bringing guns to school, arrest, low academic performance, depression, anxiety, low self-esteem, weak social relationships, and paranoid thoughts. Studies conducted suggest that young people exposed to cyberbullying cannot talk to adults about what they are going through and only a minority of them receive professional support for cyberbullying behaviors (Aktepe, 2013).

Without any geographical limitation, the electronic environment consisting of computer networks and Internet access is defined as cyber environment. While cyber environment often covers the Internet; many systems, such as mobile phones, radios, satellite, control and surveillance systems, electronic command systems, are also the elements of the cyber environment (Ozcoban, 2014). Smart phones that allow access to social media applications, such as Facebook, YouTube, Twitter, Instagram, WhatsApp, etc. provide a convenient environment for engaging in cyberbullying behavior more easily and quickly. Seferoglu et al. (2007) found out that approximately $34 \%$ of students who attend particularly secondary school and College and acquire such communication means are cyberbullies. $\mathrm{Li}$ (2007) indicates that significant number of students is exposed to cyberbullying via electronic mails, online chats and mobile phones.

Studies show that approximately 20 to $40 \%$ of adolescents exhibit cyberbullying behaviors. Males exhibit more cyberbullying behaviors than females, females are affected from cyberbullying more than males, and greater number of male students is members of social hate groups when compared to female students (Tanrikulu, 2015; Eroglu, 2011; Burnukara \& Ucanok, 2012).

It is seen that majority of the recent studies conducted in Turkey on bullying and violence are intended to determine the prevalence of bullying and violence experienced at schools, yet studies focusing on prevention are limited, not to mention the fact that the programs developed or programs provided from abroad and adapted are generally intended for elementary school students rather than College students (Piskin, 2008). Therefore, there is a need for new studies on the cyberbullying behaviors of College students.

This study investigates the cyberbullying behaviors of Sports College students, how and through which means such behaviors are exhibited, and which variables are effective in cyberbullying behaviors. Therefore, the aim of the study is to reveal whether the cyberbullying behaviors of sports College students significantly vary by certain variables, such as age, sex, economic and educational status of the family, means and frequency of following matches, attending away matches, membership of fan associations, having social media accounts, and the purpose and frequency of using social media accounts.

\section{Method}

\subsection{Model of the Research}

Since the study has intended to define and explain an existing situation, quantitative method has been used as the method and the scanning model has been used as the model. The scanning model is a research approach that aims to describe a situation that existed in the past or still exists in the manner of its existence. The phenomenon, individual or subject to research is tried to be described as is and under its own conditions. There is no attempt for changing or influencing them in any manner. The important thing is to suitably "observe" and "determine" what is desired to be known (Karasar, 1998).

\subsection{Research Group}

The research group consisted of 658 students (465 males and 193 females) studying at Sports Colleges in four different cities in Turkey during the academic year of 2018-2019.

\subsection{Data Collection Instruments}

The "Cyberbullying Scale of Sports Audience" developed by Dogar and Karaca in 2019 has been used as data collection tool. The scale consists of 7 questions, one-dimension and 5-point Likert scale. The points scored at the scale ranges from 1 to 5 , and higher scores indicate higher cyberbullying.

For the implementation of scale, firstly the necessary legal approvals were obtained, and then the researchers and their assistants went to schools and applied the scale on a voluntary basis.

\subsection{Data Analysis}

Statistical analysis of data was from IBM Statistics (SPSS, version 24, Armonk, NY, USA) package program. The skewness and kurtosis values of the points scored for the dependent variable (cyberbullying) range between +1 and -1 as shown in Table 1 . Since it was seen that the dependent variables have a normal distribution, Student t-test has been used for dual comparisons, ANOVA was used for multiple comparisons with Tukey post hoc test. The level of significance selected has been .05 . 
Table 1. Skewness and kurtosis values of cyberbullying points of sports college students

\begin{tabular}{|c|c|c|c|c|c|c|c|c|c|}
\hline & \multirow{2}{*}{$\mathrm{N}$} & \multirow{2}{*}{ Min. } & \multirow{2}{*}{ Max. } & \multirow{2}{*}{$\bar{X}$} & \multirow{2}{*}{ ss } & \multicolumn{2}{|c|}{ Skewness } & \multicolumn{2}{|c|}{ Kurtosis } \\
\hline & & & & & & Statistic & Std. Error & Statistic & Std. Error \\
\hline Cyberbullying & 658 & 1.00 & 5.00 & 1.87 & 1.038 & 1.132 & .095 & .548 & .190 \\
\hline
\end{tabular}

\section{Findings}

The data obtained from the study are given as tables, which have been used for evaluating the data.

Table 2. Cyberbullying behaviors of sports college students by age

$\mathrm{p}<.05$.

\begin{tabular}{cccccc}
\hline Age & $\mathrm{N}$ & $\bar{X}$ & ss & $\mathrm{F}$ & $\mathrm{p}$ \\
\hline Age 13-15 & 257 & 1.82 & 1.02 & & \\
Age 16-17 & 312 & 1.90 & 1.04 & & \\
Age 18 and above & 89 & 1.96 & 1.08 & .717 & .489 \\
Total & 658 & 1.88 & 1.04 & & \\
\hline
\end{tabular}

No significant difference was found in the cyberbullying behaviors of sports College students by age variable.

Table 3. Cyberbullying behaviors of sports college students by sex

\begin{tabular}{cccccc}
\hline Sex & $\mathrm{N}$ & $\bar{X}$ & $\mathrm{ss}$ & $\mathrm{T}$-test & $\mathrm{p}$ \\
\hline Male & 465 & 1.95 & 1.07 & \multirow{2}{*}{2.901} & $.004^{*}$ \\
Female & 193 & 1.69 & 0.93 & & \\
\hline
\end{tabular}

$\mathrm{p}<.05$.

Examining the cyberbullying behaviors of sports College students by the variable sex, it was seen that male students exhibited more cyberbullying behaviors than female students.

Table 4. Cyberbullying behaviors of sports college students by monthly income of their families

$\mathrm{p}<.05$.

\begin{tabular}{cccccc}
\hline Income Status & $\mathrm{N}$ & $\bar{X}$ & ss & $\mathrm{F}$ & $\mathrm{p}$ \\
\hline$\$ 0-350$ & 291 & 1.81 & .99 & & \\
$\$ 350-700$ & 285 & 1.90 & 1.06 & & \\
$\$ 701$ and above & 82 & 2.03 & 1.11 & 1.527 & .218 \\
Total & 658 & 1.88 & 1.04 & & \\
\hline
\end{tabular}

No significant difference was found in the cyberbullying behaviors of sports College students by the monthly average income of their families.

Table 5. Cyberbullying behaviors of sports college students by educational level of their fathers

\begin{tabular}{cccccccc}
\hline Level of Education & $\mathrm{N}$ & $\bar{X}$ & ss & $\mathrm{F}$ & $\mathrm{p}$ & Group & $\mathrm{P}$ \\
\hline Primary School (1) & 242 & 1.79 & 1.02 & & & & \\
Secondary School (2) & 214 & 1.77 & .94 & & & Primary- University & $.018^{*}$ \\
College(3) & 150 & 2.04 & 1.08 & 4.937 & $.002^{*}$ & Secondary-University & $.014^{*}$ \\
University (4) & 52 & 2.25 & 1.26 & & & & \\
Total & 658 & 1.88 & 1.04 & & & & \\
\hline
\end{tabular}

$\mathrm{p}<.05$.

Examining the cyberbullying behaviors of sports College students by the levels of education of their fathers, 
significant differences were found on the basis of a comparison between primary and secondary school graduates and university graduates. It was found out that the students whose fathers were primary and secondary school graduates exhibited more cyberbullying behaviors when compared to those students whose fathers were university graduates.

Table 6. Cyberbullying behaviors of sports college students by educational level of their mothers

\begin{tabular}{cccccccc}
\hline Level of Education & $\mathrm{N}$ & $\bar{X}$ & ss & $\mathrm{F}$ & $\mathrm{p}$ & Group & $\mathrm{P}$ \\
\hline Primary School (1) & 360 & 1.79 & 1.01 & & & & \\
Secondary School (2) & 187 & 1.86 & .10 & & & Primary-University & $.000^{*}$ \\
College(3) & 84 & 2.04 & 1.11 & 6.381 & $.000^{*}$ & Secondary-University & $.002^{*}$ \\
University (4) & 27 & 2.63 & 1.11 & & & High School- University & $.042^{*}$ \\
Total & 658 & 1.88 & 1.04 & & & & \\
\hline
\end{tabular}

$\mathrm{p}<.05$

Significant differences were found in the cyberbullying behaviors of sports College students by the levels of education of their mothers. It was understood that the students whose mothers were primary, secondary and College graduates exhibited more cyberbullying behaviors when compared to those students whose mothers were university graduates.

Table 7. Cyberbullying behaviors of sports college students by the means of following matches

\begin{tabular}{cccccccc}
\hline Means of Following & $\mathrm{N}$ & $\bar{X}$ & ss & $\mathrm{F}$ & $\mathrm{p}$ & Groups & $\mathrm{P}$ \\
\hline Stadium & 91 & 2.48 & 1.19 & & & Stadium-TV & $.000^{*}$ \\
TV & 249 & 1.66 & .93 & & & Stadium-Internet & $.000^{*}$ \\
Internet & 138 & 1.78 & .90 & 15.664 & $.000^{*}$ & Stadium-All & $.000^{*}$ \\
All & 180 & 1.96 & 1.07 & & & TV-All & $.011^{*}$ \\
Total & 658 & 1.88 & 1.04 & & & & \\
\hline
\end{tabular}

$\mathrm{p}<.05$

Significant differences were found in the cyberbullying behaviors of sports College students by the means of following matches. It was found out that the students who followed matches in stadiums exhibited more cyberbullying behaviors than the students that watched matches on the TV, the Internet and via all other means; whereas those students who followed matches on the TV were found to exhibit more cyberbullying behaviors than the students who watched matches via all other means.

Table 8. Cyberbullying behaviors of sports college students by the frequency of watching matches

\begin{tabular}{cccccccc}
\hline Frequency of Watching Matches & $\mathrm{N}$ & $\bar{X}$ & ss & $\mathrm{F}$ & $\mathrm{p}$ & Group & $\mathrm{P}$ \\
\hline Regularly & 177 & 2.24 & 1.13 & & & & \\
Frequently & 148 & 1.74 & .95 & & & Regularly-Frequently & $.000^{*}$ \\
Sometimes & 227 & 1.68 & .86 & & & Regularly-Sometimes & $.000^{*}$ \\
Rarely & 84 & 1.78 & 1.11 & 10.080 & $.000^{*}$ & Regularly-Rarely & $.004^{*}$ \\
I do not watch & 22 & 2.34 & 1.35 & & & Frequently-I do not watch & $.028^{*}$ \\
Total & 658 & 1.88 & 1.04 & & & & \\
\hline
\end{tabular}

$\mathrm{p}<.05$.

Significant differences were found in the cyberbullying behaviors of sports College students by the frequency of watching matches. It was found out that the students who watched matches regularly exhibited more cyberbullying behaviors than the students that watched matches frequently, sometimes and rarely; whereas those students who watched matches frequently were found to exhibit more cyberbullying behaviors than the students who did not watch matches. 
Table 9. Cyberbullying behaviors of sports college students by attending away matches

\begin{tabular}{cccccccc}
\hline Attending Away Matches & $\mathrm{N}$ & $\bar{X}$ & ss & $\mathrm{F}$ & $\mathrm{p}$ & Group & $\mathrm{P}$ \\
\hline Always & 113 & 2.23 & 1.18 & & & Always-Sometimes & $.001^{*}$ \\
Frequently & 59 & 2.35 & 1.17 & & & Always-Never & $.000^{*}$ \\
Sometimes & 210 & 1.79 & .93 & 12.027 & $.000^{*}$ & Frequently-Sometimes & $.001^{*}$ \\
Never & 276 & 1.70 & .97 & & & Frequently-Never & $.000^{*}$ \\
Total & 658 & 1.88 & 1.04 & & & & \\
\hline
\end{tabular}

$\mathrm{p}<.05$.

Significant differences were found in the cyberbullying behaviors of sports College students by the variable of going to away matches. It was found out that the students who always attended to away matches exhibited more cyberbullying behaviors than the students that sometimes or never went to away matches whereas those students who frequently went to away matches were found to exhibit more cyberbullying behaviors than the students that sometimes and never went to away matches.

Table 10. Cyberbullying behaviors of sports college students by membership of sports associations

\begin{tabular}{cccccc}
\hline & $\mathrm{N}$ & $\bar{X}$ & $\mathrm{ss}$ & $\mathrm{t}$-test & $\mathrm{p}$ \\
\hline No & 489 & 1.68 & .93 & & \\
Yes & 169 & 2.44 & 1.13 & -8.659 & $.000^{*}$ \\
\hline
\end{tabular}

$\mathrm{p}<.05$.

Significant differences were found in the cyberbullying behaviors of sports College students by the variable of membership of sports associations. It was understood that the students who were members of sports associations exhibited more cyberbullying behavior.

Table 11. Cyberbullying Behaviors of sports college students by having social media accounts

\begin{tabular}{cccccc}
\hline & $\mathrm{N}$ & $\bar{X}$ & $\mathrm{ss}$ & $\mathrm{t}$-test & $\mathrm{p}$ \\
\hline Yes & 583 & 1.85 & 1.00 & -2.121 & $.034^{*}$ \\
No & 75 & 2.12 & 1.27 & & \\
\hline
\end{tabular}

$\mathrm{p}<.05$.

Based on the variable of having social media accounts, it was found out that the students who had social media accounts exhibited more cyberbullying behaviors than the students who did not have social media accounts.

Table 12. Cyberbullying behaviors of sports college students by purposes of using social media accounts

\begin{tabular}{cccccccc}
\hline Purpose of Use & $\mathrm{N}$ & $\bar{X}$ & $\mathrm{ss}$ & $\mathrm{F}$ & $\mathrm{p}$ & Group & $\mathrm{P}$ \\
\hline Entertainment & 346 & 1.87 & 1.00 & & & & \\
Messaging & 220 & 1.86 & 1.05 & & & Entertainment-Audiovisual & $.043^{*}$ \\
Audiovisual Sharing & 44 & 2.31 & 1.26 & 3.428 & $.017^{*}$ & All-Audiovisual & $.010^{*}$ \\
All & 48 & 1.63 & .95 & & & & \\
Total & 658 & 1.88 & 1.04 & & & & \\
\hline
\end{tabular}

$\mathrm{p}<.05$.

Significant differences were found in the cyberbullying behaviors of sports College students by the variable of purpose of using social media accounts. It was found out that the students who used the social media accounts for entertainment and all purposes exhibited more cyberbullying behaviors than the students who used the social media accounts for purposes of sharing audiovisuals. 
Table 13. Cyberbullying behaviors of sports college students by the choice of device when using social media accounts

\begin{tabular}{cccccccc}
\hline Device & $\mathrm{N}$ & $\bar{X}$ & $\mathrm{ss}$ & $\mathrm{F}$ & $\mathrm{p}$ & Group & $\mathrm{P}$ \\
\hline Smart Phone & 587 & 1.85 & 1.02 & & & & \\
Tablet and Computer & 32 & 2.31 & 1.02 & & & Smart Phone-Tablet & $.041^{*}$ \\
None & 39 & 1.95 & 1.29 & 3.046 & $.048^{*}$ & & \\
Total & 658 & 1.88 & 1.04 & & & & \\
\hline
\end{tabular}

$\mathrm{p}<.05$.

Significant differences were found in the cyberbullying behaviors of Sports College students by the variable of choice of device when using social media accounts. It was understood that the students who used smart phones exhibited more cyberbullying behaviors than the students who used tablets and computers.

\section{Discussion and Conclusion}

Table 2 shows that there is no significant difference between the cyberbullying behaviors of sports College students by age variable. Studies that investigate cyberbullying behaviors by age variable suggest varied opinions. The studies conducted by Ybarra and Mitchell (2007), Cassidy et al. (2009), Vandebosch and Van Cleemput (2009), and Walvare and Heirman (2011) report no significant relationship between the age variable and cyberbullying behaviors. On the other hand, Slonje et al. (2012), Hinduja and Patchin (2010), and Mishna et al. (2012) found out significant differences between age variable and cyberbullying behaviors. On the other hand, it is possible to infer from the result of this study regarding age variable that female and male students exhibit bullying behaviors regardless of age.

Cyberbullying behaviors of sports College students showed significant difference by the variable sex, and it was determined that male students exhibited more cyberbullying behaviors than female students (Table 3). Whereas Ciftci (2005) indicates in his study on cyberbullying behaviors of Science College students that there is no significant difference between female and male students; Cetinkaya (2010), Eroglu (2011), Manap (2012), Burnukara and Ucanok (2012), Akca et al. (2015), Elmas (2016), Suslu (2016), Yelci (2018), and Igdeli (2018) conclude that male students exhibit more cyberbullying behaviors than female students, which is in parallel with the findings of this study. Such conclusion may be explained with the fact that men are freer than women, have wider elbow room, spend more time on the Internet, have a tendency to engage in bullying, violence and aggression, and the environments they spend time in are susceptible for such behaviors. Based on the findings of the study, it would rather be more appropriate to evaluate the fact that men engage in more cyberbullying behaviors taking into account the relationship between the gender roles in the Turkish culture. In the Turkish culture, this result may be associated with the fact that living conditions of women involves closer monitoring, (Erdur, 2010), and women are expected to obey the rules more in the process of socialization while foul and aggressive behaviors of men are ignored and tolerated (Akbulut, 2011; Belkis et al., 2011).

No significant differences were found in the cyberbullying behaviors of Sports College students by the monthly incomes of their families (Table 4). Koc (2011) suggested that there was no statistically significant difference among the income level of family and bully personalities and self-esteem. It was found out that there was a low-level relationship between avoidance of bullying and level of income. Cakir-Balta and Horzum (2008), Gencer (2011), and Turkoglu (2011) concluded that individuals with low level of income exhibited more cyberbullying behaviors. Olweus (1995) suggested that students' perception of the economic status of their families had an important role in bullying behaviors. The fact that no significant difference was found in the cyberbullying behaviors of the students by the income levels of their families may result from the fact that the level of average monthly income of the families was low.

Significant differences were found in the cyberbullying behaviors of the Sports College students by the levels of education of their parents (Table 5 and Table 6). It was understood that the students whose fathers were primary and secondary school graduates, exhibited more cyberbullying behaviors compared to those students whose fathers were university graduates. Similarly, it was found out that the students whose mothers were primary, secondary and College graduates exhibited more cyberbullying behaviors when compared to those students whose mothers were university graduates. Sarak (2012) suggested that there was a decrease in exhibition of cyberbullying behaviors with an increase in father's level of education; whereas Duyar (2011) pointed out that there was no significant difference in the cyberbullying behaviors by the educational status of parents. Suslu (2016) indicated that there was no significant difference between the educational level of father and the 
cyberbullying behavior. Sarak (2012) found out that there was an increase in exhibition of cyberbullying behaviors with an increase in mother's level of education. On the other hand, Serin (2012) and Tanrikulu (2013) found out that low educational level of mothers increased the cyberbullying levels of students. Accordingly, it is understood that educational level of parents is influential on the cyberbullying behaviors of Sports College students. Therefore, educational level of parents may prevent them from engaging in flexible and supportive attitudes and have positive or negative influence on the students' ability to communicate healthily.

Significant differences were found in the cyberbullying behaviors of sports College students by the means of following matches. It was found out that the students who followed matches in stadiums exhibited more cyberbullying behaviors than the students who watched matches on the TV, the Internet and via all other means. On the other hand, those students who followed matches on the TV were found to exhibit more cyberbullying behaviors than the students who watched matches via all other means (Table 7). Cetin (2015) indicated that there was similar data between the attitudes of the fans who watched matches in stadiums towards cases of violence. However, recent technological advancements have resulted in a change in the variety of methods of watching matches as matches that are broadcasted in the media industry are made available on the TV channels for a fee. Ability to watch matches on smart phones, which brings matches to the audience as close as their smart phones, on the other hand may facilitate cyberbullying behaviors.

Significant differences were found between the cyberbullying behaviors of Sports College students by the frequency of watching matches. It was found out that the students who watched matches regularly exhibited more cyberbullying behaviors than the students who watched matches frequently, sometimes and rarely whereas those students who watched matches frequently were found to exhibit more cyberbullying behaviors than the students that did not watch matches (Table 8). Turgut (2006) indicated that $72.3 \%$ of the fans watched all home matches of their teams and 19\% watched the important home matches. Bas (2008) found out that $34.4 \%$ of the fans watched all home matches, $31.5 \%$ frequently watched matches, and $16.7 \%$ rarely watched matches. Cetin (2015) indicated that men watched matches more frequently than women, individuals who frequently watched matches swore more at the team they supported, at the opponent team and at the referees and damaged the objects around them during the game. He also suggested that kids and adolescents who watched matches in places where it is possible to watch matches collectively, such as coffee houses and cafés, were more offensive against and swore more at the team they supported, the opponent team and the referees and damaged the objects around them.

Significant differences were found in the cyberbullying behaviors of sports College students by the variable of attending away matches. It was found out that the students who always attended to away matches exhibited more cyberbullying behaviors than the students who sometimes or never attended away matches. Students who frequently went to away matches on the other hand were found to exhibit more cyberbullying behaviors than the students who sometimes or never attended away matches (Table 9). Contrary to the findings of this study, Albayrak (2016) found no significant difference between the levels of aggressiveness of the fans and the variable of attending away matches. However, the fact that the fans who attend to away matches are so committed to the team they support, strengthens the likelihood that they might engage in many negative behaviors due to the competitive and challenging nature of the environment.

Based on the findings of the study (Table 10), significant differences were found in the cyberbullying behaviors of Sports College students by the variable of membership of sports associations. It was understood that the students who were members of sports associations exhibited more cyberbullying students. Bas (2008) suggested that $95.9 \%$ of the fans who exhibit bullying behaviors were members of fan associations and Sanli (2014) expressed that the fans who were members of fan associations exhibited more aggressive behaviors than those who were not members. Individuals join groups where they can socially interact in order to satisfy their needs such as belonging, finding love and value and the desire to succeed; and they exhibit emotional and cognitive commitment to and identify themselves with the group. Even when the group takes a wrong stand, they string along with the group. When in the group, the individual develops behaviors that are suitable to the norms of the group. If the group exhibits a bullying behavior, the individual who is a member of the group may also engage in such bullying behavior.

Significant differences were found in the cyberbullying behaviors of Sports College students by the variable of having social media accounts. It was found out that the students who had social media accounts exhibited more cyberbullying behaviors than the students who did not have social media accounts (Table 11). Henson et al. (2011) suggested that adolescents who had multiple social media accounts were more likely to get involved in cyberbullying. Lin et al. (2016) expressed that increased exposure to social media may result in an increased risk of cyberbullying. Igdeli (2018) suggested that individuals who had various social media memberships 
experienced more cyberbullying experiences compared to others. Accordingly, it is possible to suggest that having social media accounts facilitates cyberbullying. This is because sending messages to others on the Internet without getting their approvals, spreading baseless rumors about individuals, threats, angry messages, sharing a photograph or a document that may embarrass an individual via the social media are more common among users of social media (Lin et al., 2016). YouTube, Facebook, Instagram and Twitter are the most widely used media platforms in Turkey (Kalfa and Kocamaz, 2019).

Significant differences were found in the cyberbullying behaviors of Sports College students by the variable of purpose of using social media accounts. It was concluded that the students who used the social media accounts for entertainment and all purposes exhibited more cyberbullying behaviors than the students who used the social media accounts for purposes of sharing audiovisuals (Table 12). It is known that, in Turkey, 60 percent of young people between the ages of 15-29 use the social media mostly for entertainment purposes and one in every three young people aged 15-17 spend minimum three hours using the social media. Additionally, it is clear that nearly half the young people use the social media for purposes of spending leisure time, communicating, being up to date, and setting agendas (GSGM, 2018). Babacan (2015) suggested that majority of young people use the social media for entertainment purposes and share various contents.

Significant differences were found in the cyberbullying behaviors of Sports College students by the variable of choice of device they use during their time on social media accounts. It was understood that the students who used smart phones exhibited more cyberbullying behaviors than the students who used tablets and computers (Table 13). It is seen that similar studies on cyberbullying have not given much coverage to the variables of social media usage tools. Serin (2012) and Suslu (2016) found out that there was no significant difference between the social media usage tools and cyberbullying behaviors. The findings of such studies are different from the findings of this study. In Turkey, 71 million people that represent as high as $89 \%$ of the population have mobile subscriptions. There are 42 million people who connect to social media via their smart phones. Based on the electronic device usage statistics for the year 2018 in Turkey, it is seen that $98 \%$ of adults use mobile phones, $77 \%$ of whom are smart phone users. What is more, $48 \%$ use desktop or laptop computers, $25 \%$ use tablets. Furthermore, it was found out that people spend 7 hours on the internet, 2 hours and 48 minutes of which are spent on the social media (Internet Usage in Turkey, 2018).

It is known that many individuals who have Internet access use this technology for positive purposes such as obtaining information and sharing various contents. Nevertheless, the important thing here is that individuals should be aware that use of the available communication technology for malicious intentions is against ethical and moral rules. Contents shared by individuals who respect ethical principles and do not violate the private lives of others serve as positive models for social media users. For this reason, it could be said that violation of ethical values may result with an increase in the cyberbullying behaviors among Sports College students.

In conclusion, significant differences were found between the cyberbullying behavior of Sports College students and their age, sex, educational status of parents, means of following matches, frequency of watching games, attending away matches, membership of sports associations, having social media accounts, and purposes and levels of using such accounts. No significant difference was found in the cyberbullying behaviors of Sports College students by the income of their families.

In general, even though the cyberbullying behaviors exhibited by Sports College students change by the variables listed, it is highly likely that such behaviors will become widespread also in the cyber environment and turn into verbal and physical bullying in time. Therefore, efforts of students and teachers alone may not be sufficient in preventing the cyberbullying behaviors. It is important that families, the society and the government show the necessary sensitivity in this respect and bring into force the relevant necessary trainings and legal regulations. It is believed that this study will make positive contributions to the responsible authorities in addressing the issues of decreasing cyberbullying behaviors of Sports College students, developing positive attitude towards the social media, and avoiding cyberbullying when using the social media. Furthermore, it is predicted that this study will also be useful for similar studies to be conducted on College students.

\section{References}

Akbulut, Y., \& Eristi, B. (2011). Cyberbullying and Victimization among Turkish University Students. Australasian Journal of Educational Technology, 27(7), 1155-1170. https://doi.org/10.14742/ajet.910

Akca, E. B., Sayımer, I., \& Ergul, S. (2015). Ortaokul Ogrencilerinin Sosyal Medya Kullanimlari ve Siber Zorbalik Deneyimleri: Ankara Ornegi. Global Media Journal, TR Edition, 5(10), 71-86.

Aktepe, E. (2013). Ergenlerde Siber Zorbalik ve Siber Magduriyet. New/Yeni Symposium Journal, 51(1). 
Albayrak, V. (2016). Elazig Spora Bagli Taraftar Dernek Uyelerinin Saldirganlik Duzeylerinin İncelenmesi (Unpublished master's thesis). Firat University, Elazig.

Babacan, M. E. (2015). Gencligin Sosyal Medya Kullanim Pratikleri ve Sosyal Sermaye Iliskisi. T.C. Genclik ve Spor Bakanligi Genclik Arastirmalari Journal, 3(2), 37-65.

Balkis, M., Duru, E., \& Bulus, M. (2005). Siddete Yonelik Tutumlarin Ozyeterlilik, Medya, Siddete Yonelik İnanc, Arkadas Grubu ve Okula Baglilik Duygusu İle İliskisi. Ege Egitim Journal, 6(2), 81-97.

Bas, M. (2008). Futbolda Taraftar ve Takim Ozdeslesmesi (Trabzonspor Ornegi) (Unpublished phd thesis). Gazi University, Ankara.

Burnukara, P., \& Ucanok, Z. (2012). Okul Ortami ve Sanal Ortamda Meydana Gelen Akran Zorbaligi Ne Olcude Ortusuyor? Turk Psikoloji Journal, 27(69), 81.

Cakir-Balta, O., \& Horzum, M. B. (2008). Web Tabanli Ogretim Ortamindaki Ogrencilerin Internet Bagimliligini Etkileyen Faktorler. Ankara University, Faculty of Educational Sciences, Journal, 41(1), 187-205.

Cassidy, W., Jackson, M., \& Brown, K. N. (2009). Sticks and Stones can Break My Bones, But How can Pixels Hurt Me? Students' Experiences with Cyber-Bullying. School Psychology International, 30(4), 383-402. https://doi.org/10.1177/0143034309106948

Cengizhan, S. (2018). Internet Kullanımı ve Sosyal Medya Istatistikleri. Retrieved from https://dijilopedi.com/2018-internet-kullanimi-ve-sosyal-medya-istatistikleri/08.04.2019

Cetin, E. (2015). Cocuk ve Genclerin Televizyonda Mac Izleme Alıskanliklarinin Spordaki Siddet Eylemlerine Etkileri. International Journal of Science Culture and Sport (IntJSCS), 828-840. https://doi.org/10.14486/IJSCS351

Cetinkaya, B. (2010). Ilkogretim Ikinci Kademe Ogrencilerinde Siber Zorbaligin Yayginligi (Unpublished master's thesis). Selcuk University, Konya.

Ciftci, H. (2018). Siber Zorbalik Davranislari ve Siber Magduriyet Duzeylerinin Karsilastirilmasi. Mus Alparslan University, Social Sciences Journal, 6(6), 887-897.

Dogar, Y., \& Karaca, Y. (2019). Spor Seyircilerinin Zorbalik Davranislarinin Incelenmesi (Unpublished phd thesis). Inonu University, Malatya. https://doi.org/10.31589/JOSHAS.110

Duyar, D. (2011). Futbol Seyircisinde Saldirganlik Davranislarinin Incelenmesi (Unpublished master's thesis). Selcuk University, Konya.

Elmas, B. (2016). Ogretmen Adaylarinin Siber Zorbalik ve Siber Magduriyet Algi Duzeylerinin Incelenmesi (Unpublished master's thesis). Afyon Kocatepe University, Afyon.

Erdur, B. O. (2010). Cyberbullying and Its Correlations to Traditional Bullying, Gender and Frequent and Risky Usage of Internet-Mediated Communication Tools. New Media \& Society, 12(1), 109-125. https://doi.org/10.1177/1461444809341260

Eroglu, Y. (2011). Kosullu Oz-Deger, Riskli Internet Davranıslarl ve Siber Zorbalık / Magduriyet Arasindaki Iliskinin Incelenmesi (Unpublished master's thesis). Sakarya University, Sakarya.

Gencer, S. L. (2011). Ortaogretim Ogrencilerinin Internet Baglmlilik Durumlarinin Internet Kullanim Profilleri ve Demografik Ozelliklere Gore Farkliliklarinin Incelenmesi (Unpublished master's thesis). Suleyman Demirel University, Isparta.

GSGM. (2018). Genclik ve Spor Bakanligi Sosyal Medya Arastirmasi. Retrieved from http://www.gsb.gov.tr/HaberDetaylari/1/3816/genclik-ve-spor-bakanligi-turkiyenin-en-kapsamli-sosyal-med ya-arastirmasini-yapti.aspx 11.12.2018.

Gur, K., \& Kucuk, L. (2010). Ruh Sagligi Sorunu: Okullarda Zorbalık. Sted Journal, 19(2), 85-89.

Henson, B., Reyns, B. W., \& Fisher, B. S. (2011). Security in the 21st Century: Examining the Link Between Online Social Network Activity, Privacy, and Interpersonal Victimization. Criminal Justice Review, 36(3), 253-268. https://doi.org/10.1177/0734016811399421

Hinduja, S., \& Patchin, J. W. (2010). Bullying, Cyberbullying, and Suicid. International Academy for Suicide Researche.

Igdeli, F. (2018). Universite Ogrencilerinin Siber Zorbalik ve Siber Magduriyet Duyarliliklarinin Cesitli Degiskenler Baglaminda Incelenmesi (Unpublished master's thesis). Anadolu University, Eskisehir. 
Kalfa, M., \& Kocamaz-Adas, S. (2019). Sosyal Medyayi Kullanim Acisindan Genclik ve Spor Bakanliginin Analizi. Turk Spor Bilimleri Journal, 2(1), 8-21. Retrieved from http://dergipark.gov.tr/tsbd/issue/44025/516457

Karasar, N. (1998). Bilimsel Arastirma Yontemi (8th ed.). Nobel Publications, Ankara.

Kowalski, R. M., Limber, S. P., \& Agaston, P. W. (2012). Cyber Bullying: Bullying in Digital Age (2nd ed.). Wiley-Blackwell Publication, Malden MA 02148-5020, USA.

Li, Q. (2007). New Bottle But Old Wine: A Research of Cyberbullying in Schools. Computers in Human Behavior, 23(4), 1777-1791. https://doi.org/10.1016/j.chb.2005.10.005

Lin, L. Y., Sidani, J. E., Shensa, A., Radovic, A., Miller, E., Colditz, J. B., \& Primack, B. A. (2016). Association Between Social Media Use and Depression among U.S. Young Adults. Depression and Anxiety, 33(4), 323-331. https://doi.org/10.1002/da.22466

Manap, A. (2012). Ilkogretim Ikinci Kademe Ogrencileri ve Siber Zorbalik: Samsun Ili Ornegi (Unpublished master's thesis). Ondokuz Mayis University, Samsun.

Mishna, F., Khoury-Kassabri M., Gadalla, T. \& Daciuk, J. (2012). Risk Factors for Involvement in Cyber Bullying: Victims, Bullies And Bully-Victims. Children and Youth Services Review, 34, 63-70. https://doi.org/10.1016/j.childyouth.2011.08.032

Olweus, D. (1995). Bullying or Peer Abuse at School: Facts and Intervention. Current Directions in Psychological Science, 4, 196-200. https://doi.org/10.1111/1467-8721.ep10772640

Ozcoban, C. (2014). 21. Yuzyilda Ulusal Guvenligin Saglanmasinda Siber Istihbaratin Rolu (Unpublished master's thesis). Istanbul: Harp Akademileri.

Peter, K., Smith, J. M., Manuel, C., Sonja, F., Shanette, R., \& Neil, T. (2008). Cyberbullying: Its Nature and Impact in Secondary School Pupils. Journal of Child Psychology and Psychiatry, 49(4), 376-385

Piskin, M. (2008). Okul Siddetinin Yayginligi Ogrenciler Uzerindeki Olumsuz Etkileri ve Onleme Programlarinin Degerlendirilmesi. Siddet Karsiti Dusunce Ortamı (Symposium book, pp. 73-86). Fisek Enstitusu Calısan Cocuklar Bilim ve Eylem Merkezi Foundation, Ankara.

Sanli, S. (2014). Futbol Musabakalarinda Olaylarda Yer Alan Seyircilerin Saldirganlik Duzeylerinin Incelenmesi (Unpublished phd thesis). Gazi University. Ankara

Sarak, O. (2012). Lise Ogrencilerinde Sanal Zorbalik (Unpublished Master's Thesis). Halic University, Istanbul.

Serin, H. (2012). Ergenlerde Siber Zorbalik/Siber Magduriyet Yasantilari ve Bu Davranislara Iliskin Ogretmen Ve Egitim Yoneticilerinin Gorusleri (Unpublished Pphd thesis). Istanbul University, Istanbul.

Slonje, R., Smith, P. K., \& Frisen, A. (2012). Processes of Cyberbullying, and Feelings Of Remorse By Bullies: A Pilot Study. European Journal of Developmental Psychology, 9, 244-259. https://doi.org/10.1080/17405629.2011.643670

Suslu, D. P. (2016). Lise Ogrencilerinin Siber Zorbalik ve Siber Magduriyetlerinin Benlik Saygisi Anne Baba ve Akran Iliskileri Acisindan Incelenmesi (Unpublished phd thesis). Istanbul Maltepe University, Istanbul.

Tanrikulu, I. (2015). Siber Zorbalik Yapma Motivleri ile Kisilik Ozellikleri Arasındaki Iliskiler: Kullanimlar ve Doyumlar Kuramini Test Etme (Unpublished phd thesis). Institute of Social Sciences, Division of Educational Sciences, Middle East Technical University, Ankara.

Tanrikulu, T. (2013). Siber Zorbalikla Iliskili Degiskenlerin Incelenmesi ve Gerceklik Terapisi Yonelimli Bir Mudahale Programinin Siber Zorbaca Davranislar Uzerindeki Etkisi (Phd Thesis, Educational Sciences Institute, Department of Educational Sciences, Sakarya University, Sakarya).

Turgut, M. (2006). Fenerbahce Spor Kulubu Orgutlu Taraftarlarinin Taraftarlik Anlayislari Uzerine Bir Arastirma (Unpublished Phd Thesis). Gazi University, Ankara.

Turkoglu, S. (2013). Ergenlerin Problemli Internet Kullanimlari ile Siber Zorbalik Egilimleri Arasindaki Iliskinin Incelenmesi (Unpublished master's thesis). Marmara University, Istanbul.

Vandebosch, H., \& Van Cleemput, K. (2009). Cyberbullying among Youngsters: Profiles of Bullies and Victims. New Media \& Society, 11(8), 1349-1371. https://doi.org/10.1177/1461444809341263

Walrave, M., \& Heirman, W. (2011). Cyberbullying: Predicting Victimisation and Perpetration. Children \& Society, 25, 59-72. https://doi.org/10.1111/j.1099-0860.2009.00260.x 
Ybarra, M., \& Mitchell, K. P. (2007). Revalence and Frequency of Internet Harassment Instigation: Implications for Adolescent Health. Journal of Adolescent Health, 41, 189-195. https://doi.org/10.1016/j.jadohealth.2007.03.005

Yelci, H. (2018). Ortaokul Ogrencilerinde Siber Zorbalik ile Saldirganlik Iliskisinin Incelenmesi (Unpublished master's thesis). Istanbul University, Istanbul.

Yigit, M. F., \& Seferoglu, S. D. (2017). Siber Zorbalikla Iliskili Faktorler ve Olasi Cozum Onerileri Uzerine Bir Inceleme. Online Journal of Technology Addiction \& Cyberbullying, 4(2), 13-49.

\section{Copyrights}

Copyright for this article is retained by the author(s), with first publication rights granted to the journal.

This is an open-access article distributed under the terms and conditions of the Creative Commons Attribution license (http://creativecommons.org/licenses/by/4.0/). 